\title{
GEOCONSERVATION IN PROTECTED AREAS
}

\author{
Roger Crofts $^{1 *}$ and John E. Gordon ${ }^{2}$ \\ *corresponding author: roger.dodin@btinternet.com \\ ${ }^{1}$ WCPA Emeritus and WCPA Geoheritage Specialist Group, Scotland \\ ${ }^{2}$ WCPA Geoheritage Specialist Group, Scotland
}

\section{ABSTRACT}

Formal recognition of the geodiversity component of protected areas was made in 2008 in the revised IUCN Guidelines for Applying Protected Area Management Categories. This article argues the importance of this addition and states the case for geoheritage conservation in protected areas, both in its own right and for its wider value in supporting biodiversity and ecosystem services. The article summarises some of the key issues which protected area managers will need to address in ensuring that geoconservation is adequately reflected in protected area development and management. Preliminary guidance on the development of geoconservation in protected areas and the relevance of the six management categories is provided.

Key words: geodiversity, geoheritage, geoconservation, protected area management

\section{INTRODUCTION}

The revision of the IUCN definition of a protected area brought about a fundamental change in the primary focus from biodiversity to the broader concept of nature (Dudley, 2008). The contrast between the previous definition and the current one is clear from the following texts:

- 'An area of land and/or sea especially dedicated to the protection and maintenance of biological diversity, and of natural and associated cultural resources, and managed through legal or other effective means' (IUCN, 1994).

- 'A clearly defined geographical space, recognised, dedicated and managed, through legal or other effective means, to achieve the long-term conservation of nature with associated ecosystem services and cultural values' (Dudley, 2008).

This crucial broadening of the definition of 'diversity' was debated and agreed at the IUCN Protected Areas Categories Summit in Almeria, Spain, in May 2007. It is reflected in the summary of proceedings by the statement that "protected areas should address a full range of issues associated with "diversity", including the need for protection of geological and soil diversity' (Dudley \& Stolton, 2008, p.194). The 2008 Guidelines elaborate the point further by explaining that 'nature always refers to biodiversity, at genetic, species and ecosystem level, and often also refers to geodiversity, landform and broader natural values' (Dudley, 2008, p.9).
The critical issue is how to ensure that geodiversity is adequately reflected in protected area development and management. To aid this process, IUCN WCPA has established the Geoheritage Specialist Group ${ }^{1}$ chaired by Professor Kyung Sik Woo which has, among other tasks, to produce a best practice guideline on the management of protected area geodiversity and develop IUCN background protected area geoheritage guidance material $^{2}$. In the interim, generic guidance has been produced as part of the protected area governance and management handbook being released at the 2014 World Parks Congress (Crofts \& Gordon, 2015).

\section{DEFINING GEODIVERSITY AND GEOCONSERVATION}

Readers will be familiar with the definition of biodiversity, but perhaps less so with the definition of geodiversity and its component parts. It was described in the IUCN Management Guidelines as: '[g]eodiversity is the variety of rocks, minerals, fossils, landforms, sediments and soils, together with the natural processes which form and alter them' (Dudley, 2008, p.66). In more detail, geodiversity is: 'the natural range (diversity) of geological (rocks, minerals, fossils), geomorphological (landforms, topography, physical processes) and soil and hydrological features. It includes their assemblages, structures, systems and contributions to landscapes' (Gray, 2013, p.12). Basically, therefore, geodiversity is the abiotic equivalent of biodiversity. 


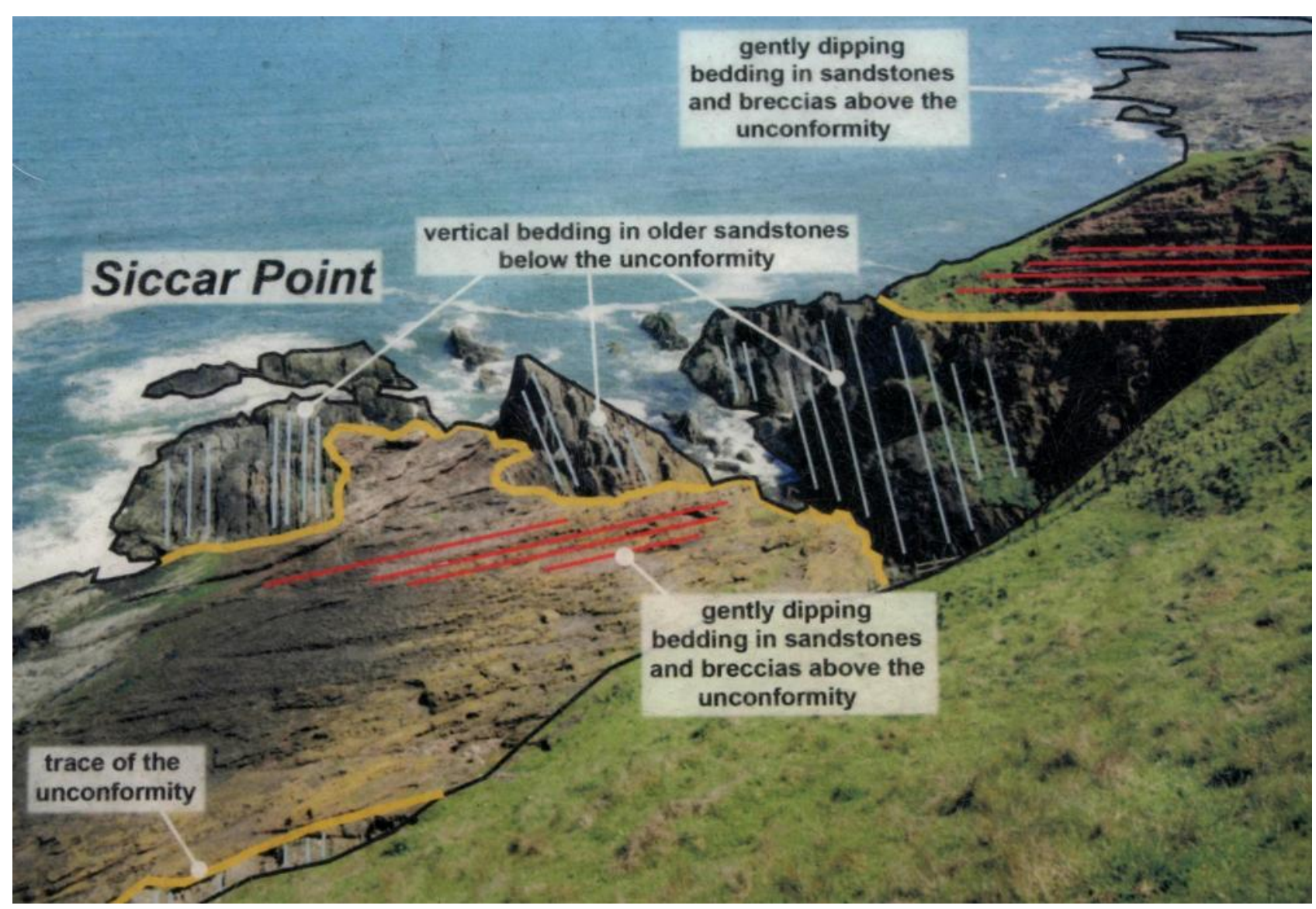

Siccar Point, Berwickshire, Scotland: a key locality in the development of ideas about the age of the Earth, where James Hutton in $\mathbf{1 7 8 8}$ identified a huge gap in geological time represented by the unconformity between the steeply dipping lower rocks and those at a more gentle angle on top @ Roger Crofts

Unpacking the definition a little further to be of relevance to protected areas requires two further terms to be defined.

Geoheritage comprises those elements of the Earth's geodiversity that are considered to have significant scientific, educational, cultural or aesthetic value (DíazMartínez, 2011; ProGEO, 2011; Geological Society of America, 2012). Put in everyday language, 'our geoheritage is the story of the Earth; a narrative through time preserved in its rocks, landforms, fossils, minerals and soils that provides a strong case for geoconservation' (Crofts \& Gordon, 2015). There is a responsibility to ensure this inheritance from the past is passed on to future generations. In practice, a site or area of high geoheritage significance can comprise a single feature of value, and does not need to have a diversity of features present.

How these interests are managed is encompassed by the term geoconservation, defined broadly as: "he conservation of geodiversity for its intrinsic, ecological and (geo)heritage values" (Sharples, 2002, p.6). More specifically, it has been defined as 'action taken with the intent of conserving and enhancing geological, geomorphological and soil features and processes, sites and specimens, including associated promotional and awareness raising activities, and the recording and rescue of data or specimens from features and sites threatened with loss or damage' (Prosser, 2013, p.568).

It should be clear from these definitions that geoconservation essentially involves the care, management and promotion of geoheritage in protected areas (ProGEO, 2011). In addition, it includes the conservation of geodiversity in a broader sense to ensure the functioning of healthy ecosystems and the services they provide. Geoconservation embraces individual features and collections of features, and also the past and present natural processes of landscape evolution and change. And, in the case of dynamic features and sites, it requires consideration of abiotic processes at the larger, ecosystem scale. For example, conserving the features of a river valley because of the biodiversity and geodiversity interest and importance cannot be sustained without ensuring that the water regime upstream of the protected area is not radically changed unnaturally or significantly damaged by human activity. So geoconservation is broad ranging, and not, as sometimes thought, just about preserving individual features at the site level. 
To be clear, the term geoconservation used in this paper embraces both the specific conservation of geoheritage assets and the wider conservation of the processes, functions and features which constitute geodiversity.

The importance of geoconservation and its integration into the management of protected areas, as part of the Ecosystem Approach (as defined by the CBD), that recognises the values and integrity of both abiotic and biotic processes in nature conservation, has been approved by successive IUCN World Conservation Congresses. IUCN Resolutions 4.040 at Barcelona (IUCN, 2008) and 5.048 at Jeju (IUCN, 2012) both clearly state that geodiversity is part of nature and geoheritage is part of natural heritage.

\section{STATING THE CASE FOR GEOCONSERVATION}

Having settled the definition of terms, the question then arises 'why is geoconservation necessary?' There is a popular view that rocks and landforms are reasonably robust and not liable to change or damage by human activities and therefore do not need special measures for their conservation. But this is not the case (see threats below). There are five basic reasons for the conservation of geoheritage and geodiversity: 1) for their own sake, 2) as a scientific and educational resource, 3) for their cultural and aesthetic values, 4) as the abiotic equivalent of biodiversity and 5) for the provision of environmental goods and ecosystem services.

Conserving nature because of its intrinsic value is vitally important. Too often in the recent past the focus has been exclusively on the usefulness of diversity to society. Now is the time to recognise that, despite the fact this is currently the Anthropocene period of geological time, there is ample justification for protecting our geoheritage just because it is there: for its own sake and for life's sake (see Crofts et al., 2008).

Protecting geoheritage as a scientific and educational resource is the second reason. There are many sites that have proved to be formative in our knowledge of the evolution of the Earth. Two examples suffice to point out their importance. Hutton's unconformity at Siccar Point, Berwickshire, Scotland, is one of the key sites where James Hutton, 'the father of modern geology', advanced his theory of the Earth encapsulated in the timeless statement that 'we see no vestige of a beginning, - no prospect of an end' (Hutton, 1788, p.304). The Burgess Shale in Yoho and Kootenay National Parks, British Columbia, Canada, provides exceptional insights into the evolution of complex life forms on Earth over 500 million years ago during the Cambrian period3.

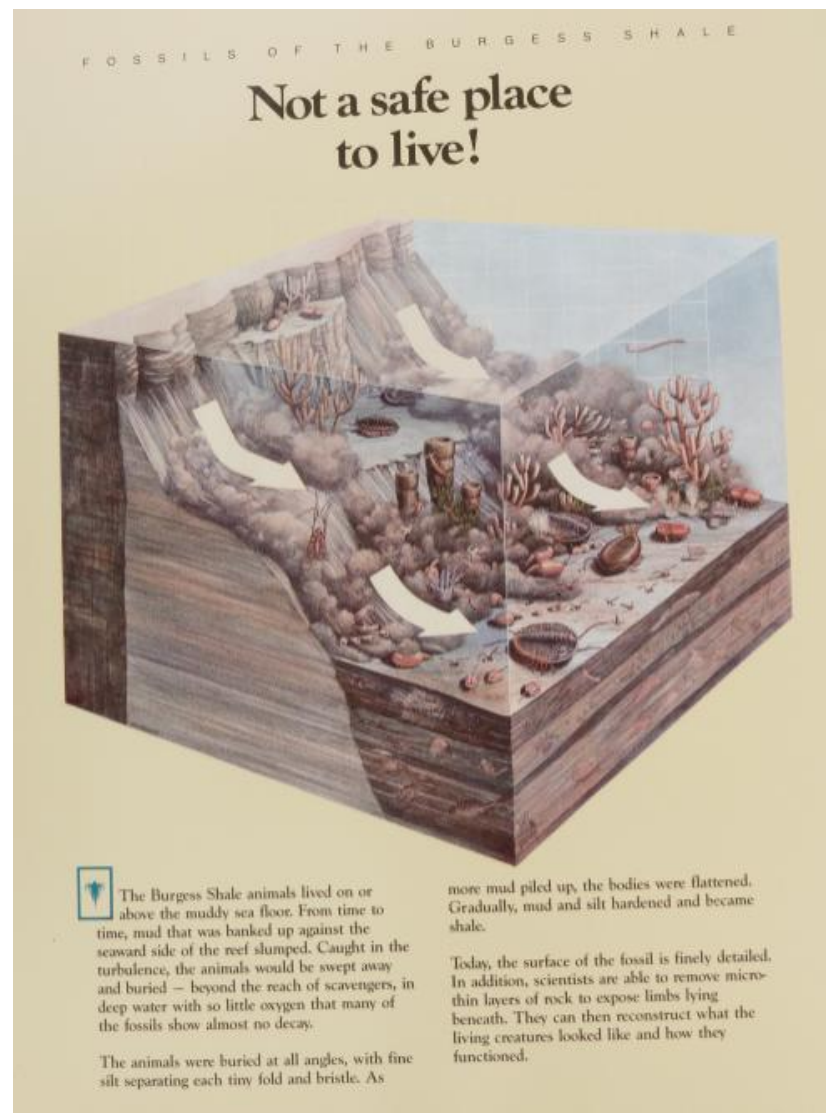

The great diversity of fossils present and their remarkable degree of preservation in the Burgess Shale, British Columbia, Canada, have allowed new insights into the evolution of life on Earth. Site management includes restricted access to the site to protect the fossils, accompanied by excellent interpretation at the Yoho National Park visitor centre in Field (c) Roger Crofts

Related to this second reason is the fact that there will be some aspects of Earth systems and features which our current knowledge does not recognise or does not understand. We should be aware of leaving an inheritance to future generations to research and explore as part of our educational and cultural resources. At the very least, sites and features which have proved to be controversial in their interpretation or resulted in important or new insights into the evolution of the Earth and life upon it are likely to be worthy of protection.

A third reason for geoconservation in protected areas is its important cultural heritage role. For example, in Slovenia the mountain, Triglav, in the national park of the same name, is represented on the national flag (see overleaf). Similarly, there are many sacred sites, such as groves in India, and many cultural history sites such as the caves with early paintings of life in Kwa-Zulu Natal, South Africa, that demonstrate the close connection between geoheritage and cultural heritage. Some sites, such as Yosemite and Yellowstone National Parks in the USA, have a cultural importance because of their role in the development of protected areas thinking and action, 


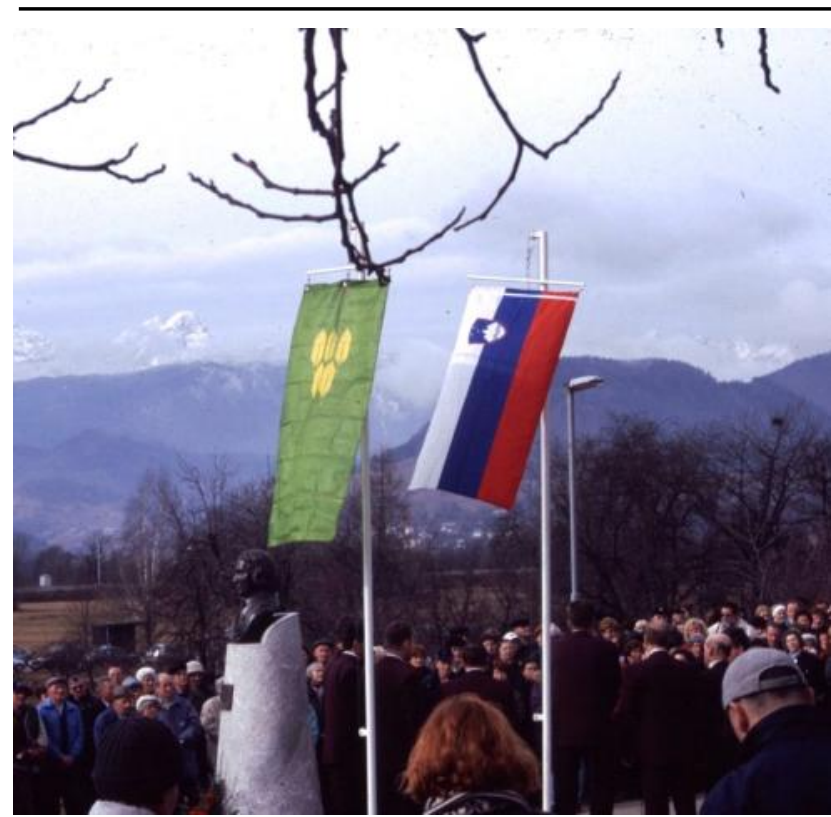

Triglav, the highest mountain in Slovenia, at the heart of the Triglav National Park, is also the key symbol on the national flag of the new state formed in 1990 @ Roger Crofts

while many others have significant value for aesthetic reasons and for recreation and tourism activities (Coratza \& Panizza, 2009; Dowling \& Newsome, 2010).

As geodiversity is widely regarded as the abiotic equivalent to biodiversity (Gray, 2013; Crofts, 2014), it has equal justification for being a key element in protected areas as an integral part of nature and natural heritage: the fourth reason. By definition, geodiversity is a vital component of ecosystems in which biotic and abiotic components form an interacting system (Tansley, 1935; Convention on Biological Diversity, 1992). The linkages and interdependencies between abiotic and biotic nature are clear across a wide range of scales from global to local (e.g. Soukupová et al., 1995; Barthlott et al., 2005; Alexandrowicz \& Margielewski, 2010). The substrate of rocks and soils provides the rooting zone and much of the nutrient supply for plant growth and survival. The specific characteristics of the substrate and soil - acidity/alkalinity, moisture retention capacity, chemical composition, and others, determine its capacity to host plants and animals. So, in some cases, the chemical composition of the rocks will determine particular plant types which are so unusual that they justify protection, as for example those growing on the serpentine rocks of the Keen of Hamar in Shetland, UK4, and the thermophilic plants dependent on the enriched chemical cocktail in the Waimangu volcanic valley, Rotorua, New Zealand5. Equally important are the dynamic processes (e.g. soil formation, biogeochemical and water cycling, stream flows, erosion and sedimentation) that provide nutrients and maintain habitat condition and ecosystem

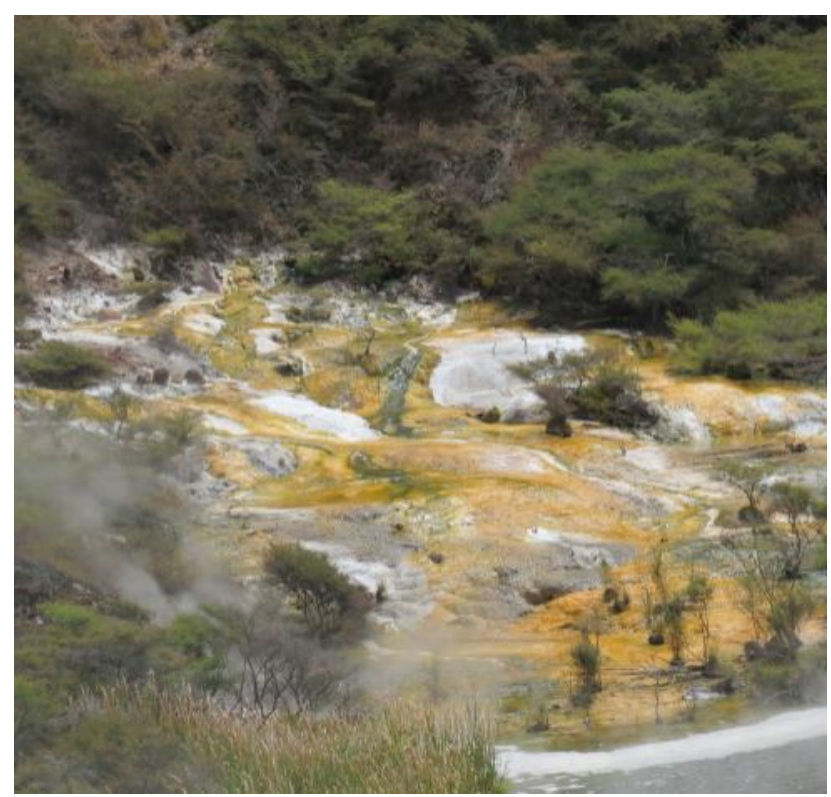

Thermophilic plants represent biotic dependency on the nutrients provided by hydrothermal activity in Waimangu volcanic valley, Rotorua, New Zealand (c) Roger Crofts

health. Hence, in many environments the complex and dynamic patterns of micro- and meso-scale topography, soils and geomorphological processes provide mosaics of habitats, corridors and topographical variations for high species richness (Thorp et al., 2010; le Roux \& Luoto, 2014).

This biotic-abiotic relationship can also be described in a different way. The recently coined term 'conserving the stage' is based on flora and fauna being the actors and geodiversity as the stage on which they thrive. In this approach, the conservation of biodiversity is seen as best achieved by conserving the stage, particularly in times of climate change when having a range of habitats for plants and animals to relocate to may be crucial to their survival (Anderson \& Ferree, 2010).

And, finally, geodiversity provides many environmental goods and ecosystem services (Figure 1) (Gray et al., 2013). This provision means that working with nature, rather than against it, and seeking to maintain the natural systems and processes is a fundamental role of protected area management.

Three specific examples illustrate the case for geoconservation.

Joggins Fossil Cliffs, Canada: This World Heritage Site (WHS) on the shores of the Bay of Fundy, Nova Scotia, Canada, represents the conservation of a key site for Earth history because of the knowledge gained from analysis of the fossil flora and fauna in the rock strata. It is the finest example in the world of a fossilised terrestrial tropical ecosystem and its associated plant and 


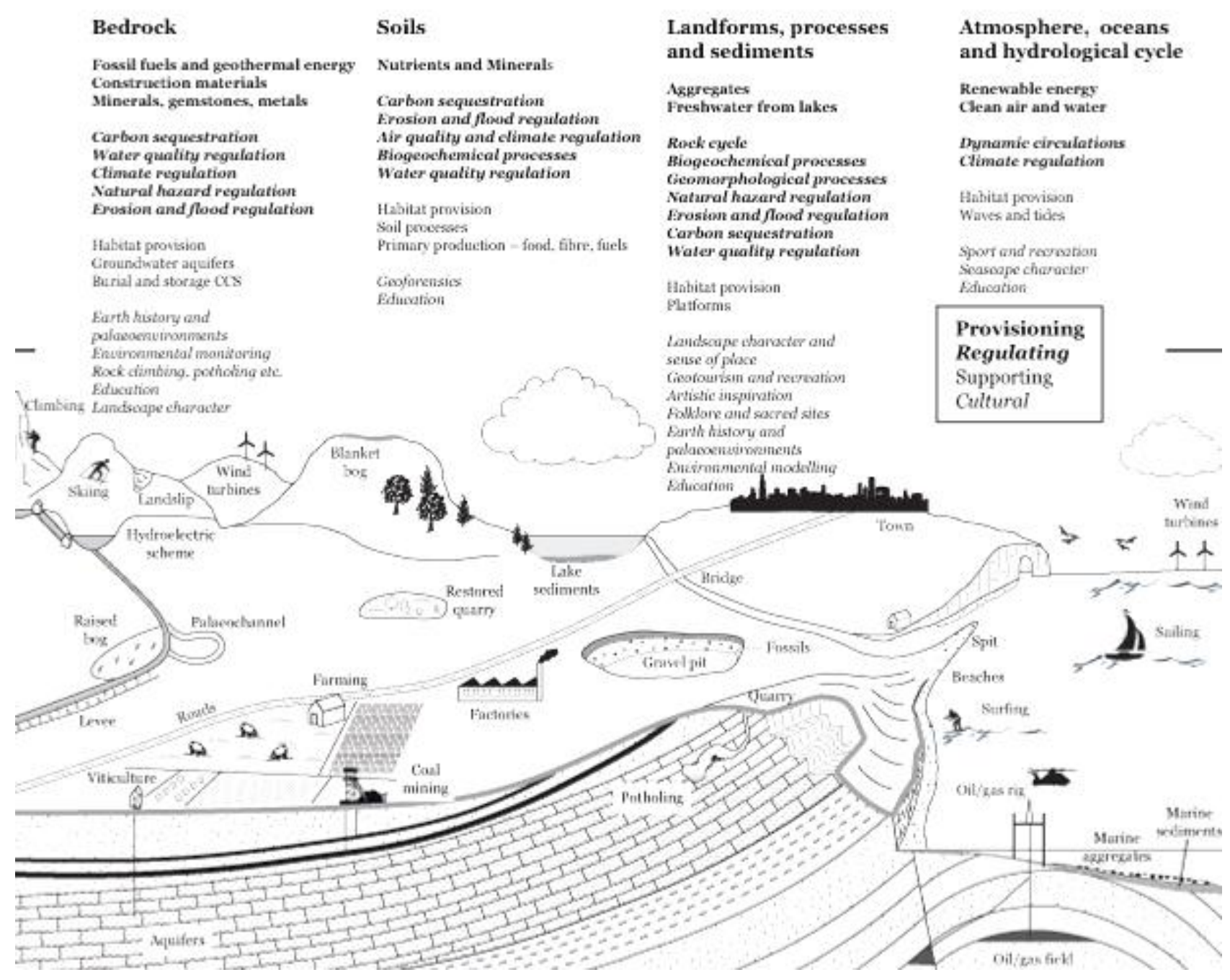

Figure 1: Schematic illustration of the goods and services derived from geodiversity. Reprinted from Proceedings of the Geologists' Association 124, M. Gray, J.E. Gordon \& E.J. Brown, 'Geodiversity and the ecosystem approach: the contribution of geoscience in delivering integrated environmental management', 659-673, Copyright (2013), with permission from Elsevier <http://www.sciencedirect.com/science/journal/00167878>

animal remains dating from around 310 million years ago during the Carboniferous period. The first reptiles known were discovered here and the fossils represent the evolution of life from amphibians to reptiles. Joggins Fossil Cliffs also provides the possibility of discovering new species and of new interpretations of plant and animal history by future generations of scientists, especially as it is subject to shoreline erosion by the highenergy tidal currents and waves in the Bay of Fundy exposing new sections continually. The site was also important in the development of ideas about the evolution of life on Earth through the visits of scientists in the mid-19th century - including Charles Darwin and Sir Charles Lyell, who discovered new amphibian fossils at Joggins Cliffs and whose ideas on the geological evolution of the Earth over vast time periods helped to underpin Darwin's theory of biological evolution. Most importantly, there is interpretation and education of the highest quality provided for visitors of all ages and abilities in the visitor centre and along the shoreline through the trained official guides ${ }^{6}$ (see photo overleaf).

The site is protected under conservation legislation of the provincial government of Nova Scotia, backed up by the WHS designation and the monitoring process associated with it. Surprisingly, in a country where major conservation sites and areas are under federal ownership and jurisdiction through Parks Canada, the site is privately owned and run by an NGO, albeit financially supported from public sources.

Vatnajökull National Park, Iceland: There are many reasons for the protection of Iceland's, and Europe's, largest ice cap and its outlet glaciers, meltwater streams and sandur plains. It is underlain by a tectonic plate boundary with active subglacial volcanoes, such as Grímsvötn, and surface fissure belts, such as Laki. These sites are important in understanding the interaction 


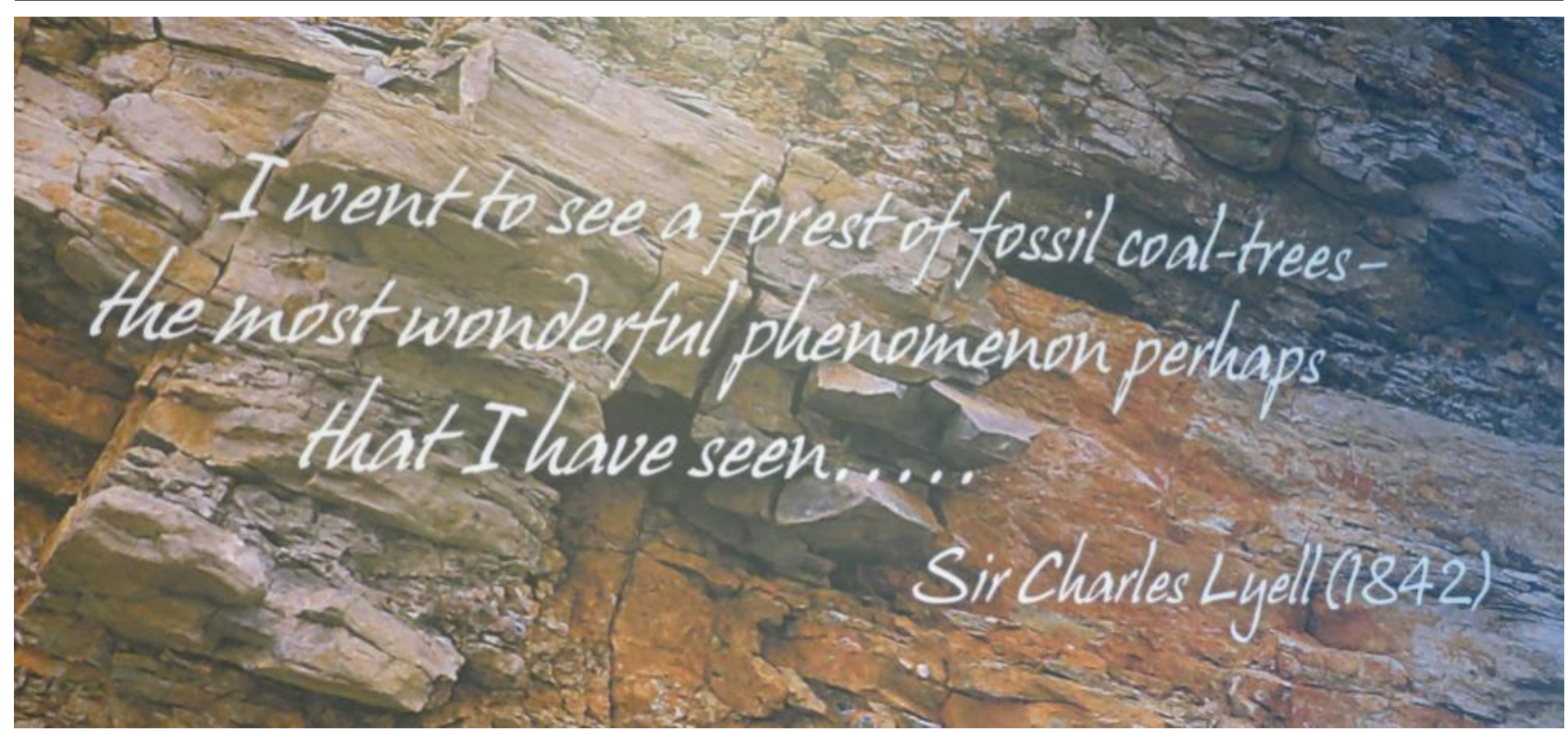

Joggins Fossil Cliffs World Heritage Site, Nova Scotia, Canada, is an exemplary geoheritage site for discovering biological evolution during an important period in the Earth's history. Continual coastal erosion of the cliffs provides new exposures for scientific study and for public viewing. An excellent interpretation centre is located discretely on the cliff top $\odot$ Roger Crofts

between subglacial volcanic eruptions and ice caps, producing high-magnitude floods that shape the existing sandur plains and build the land out into the adjacent ocean. The rivers flowing from the ice margin provide nutrients to support plant growth and the sandur plains provide food and habitat for breeding arctic animal species, such as the Great Skua (Catharacta skua) and the Red-throated diver (Gavia stellata). The arctic environment adjacent to the ice cap is ideal for the formation of periglacial forms such as palsas (low mounds formed by ice lenses just below the ground surface). It also provides informal recreational opportunities, including the ascent of Iceland's highest mountain, and snow scooter tours in winter. Cultural history is also significant, particularly in the many folk tales and legends, the grazing of sheep on the upland heaths and sandur plains, and the skills of local people in navigating their way across the highly hazardous sandur plains with their shifting channels and sinking sands. There is access by the public to the edge of some of the outlet glaciers and ice-dammed lagoons, as well as to the ice cap and the surrounding land. Interpretation facilities explain the geoheritage significance of the protected area, especially at Skaftafell in the south (Guttormsson, 2011).

The national park is protected under a specific Icelandic Act of Parliament. There are remaining threats which, without the existence of the park, would be significantly higher. The park helps to protect the main river systems from exploitation for hydro-electric power, although what legitimately should have been areas protected within the park have now been dammed for hydroelectric power production.
The Giant Mountains, Czech Republic-Poland: The Giant Mountains, located astride the Czech-Polish border, are part of the Sudetes mountain belt formed in the late Carboniferous during the Hercynian orogeny. They are the highest and most northern mountain massif in central Europe. They are outstanding for inter-related geodiversity, biodiversity and cultural interests. The area has been described as 'an arctic-alpine island' in the middle of Europe, forming a 'biogeographical crossroads' with affinities to the Alps to the south and the Scandinavian mountains to the north (Soukupová et al., 1995; Štursa, 1998). Exceptionally for the middle mountains of Central Europe, the summits and plateau surfaces rise above the alpine tree line and display a remarkable assemblage of relict and active periglacial features, including tors, cryoplanation terraces, blockfields, blockslopes, solifluction features, nivation hollows and patterned ground. Of particular interest is the so-called 'arctic-alpine tundra' zone and the close associations between plant distributions, topography, geomorphology and climatic factors (Soukupová et al., 1995; Jeník, 1997). Three aspects are of particular significance (Soukupová et al., 1995; Štursa, 2013): 'lichen tundra' developed on the blockfields of the higher summits; alpine grassland with vegetated patterned ground, scattered stands of dwarf pine (Pinus mugo) and subalpine mires on adjacent etchplains; and short- to long-lying snowbeds with related hydrological systems and snow avalanche-related plant and animal communities in the leeward of glacial cirques and valley heads. The Giant Mountains have a long history of human activity and today face a range of human pressures, including those from high visitor numbers in summer and winter. 


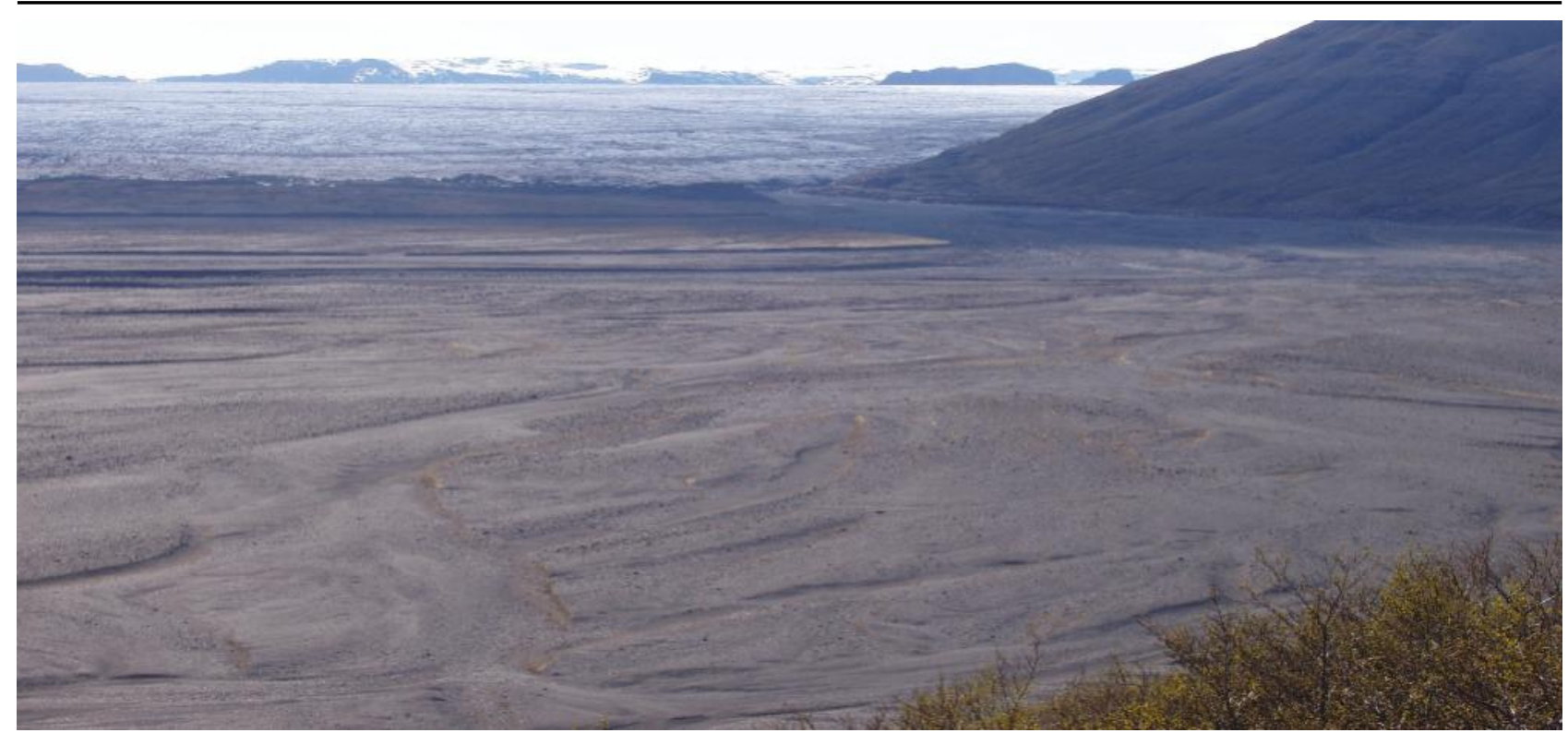

The Skeiðarársandur outwash plain and river systems emanating from the Skeiðarárjökull, Vatnajökull National Park, Iceland: an intensely dynamic environment with rapid changes in water discharge and velocity, such as occurred in 1996 when a subglacial eruption melted the overlying ice and caused a major flood @ Roger Crofts

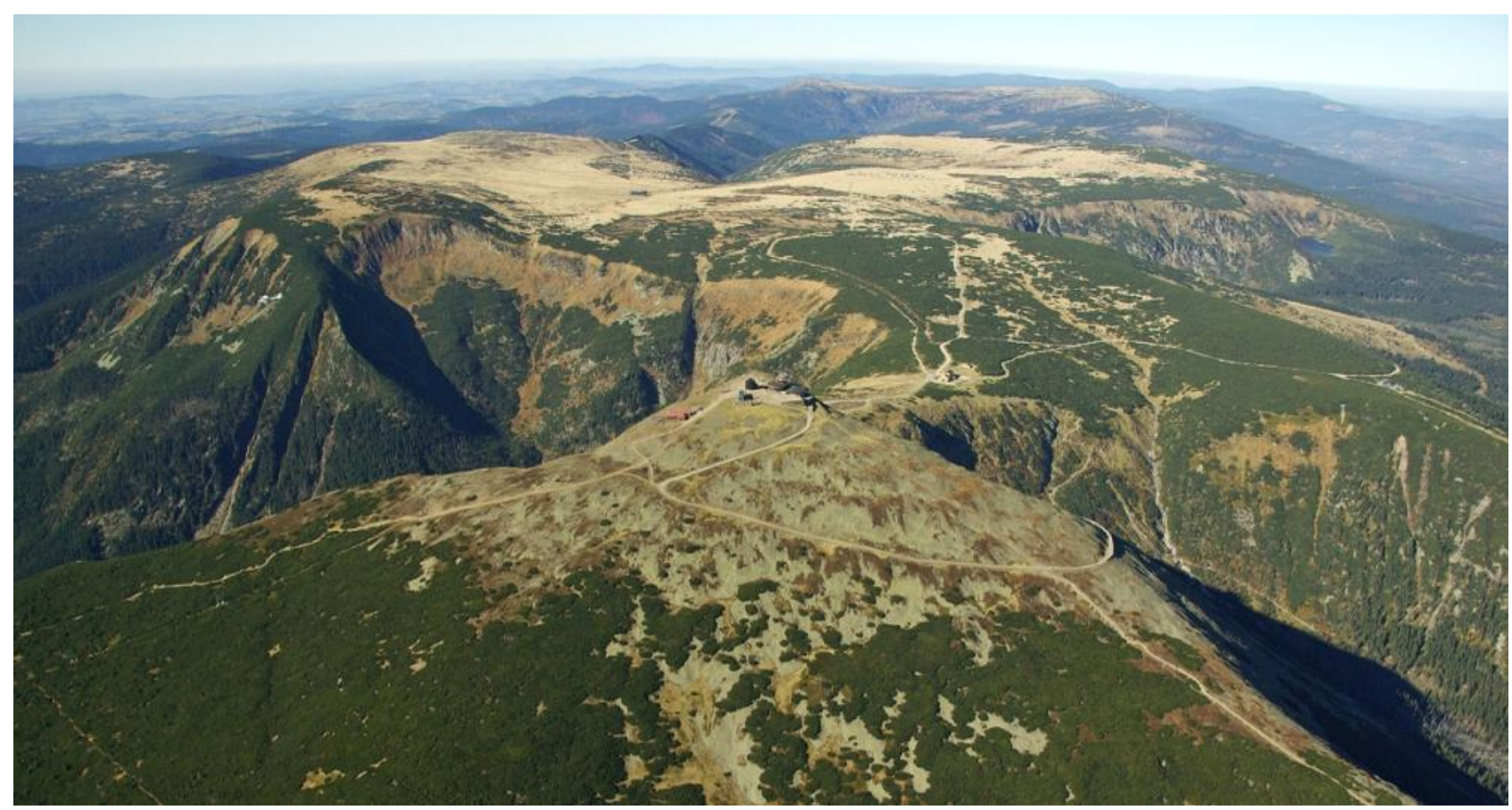

The Giant Mountains: lichen-covered blockfields and cryoplanation terraces occur on the higher summits, with vegetated patterned ground, stands of dwarf pine (Pinus mugo) and subalpine mires on the plateau slopes below. The adjacent glacial corries support a great diversity of plants on the leeward slopes associated with snow avalanche paths and snow beds (C) Kamila Antošova/KRNAP

Protection and management are co-ordinated under the cross-border Czech-Polish Krkonoše/Karkonosze National Parks and the Krkonoše/Karkonosze Transboundary Biosphere Reserve. Management recognises the importance of maintaining natural geomorphological processes as the driving force for supporting diversity in the mountains (Štursa, 2013). Popular publications and material for visitors also emphasise the links between geodiversity, biodiversity and cultural heritage in an exemplary manner ${ }^{8}$.

\section{IDENTIFYING SITES AND AREAS FOR GEOCONSERVATION}

The basic approach recommended by IUCN WCPA for identification of protected areas rests on the categorisation of biogeographical regions (Davey, 1998) and key biodiversity areas (Langhammer et al., 2007). However, a somewhat different approach is required for the identification of sites for geoconservation. A staged approach is suggested both for the identification of the 
Table 1: Key scientific elements of a geoheritage protected areas system. Source: Crofts \& Gordon (2015)

Key elements

\begin{tabular}{|c|c|}
\hline Key stages in Earth history & $\begin{array}{l}\text { Stratotypes (type sections) and type localities designated as the standard reference } \\
\text { sections and geographic localities for named stratigraphic units (rock strata defined } \\
\text { according to their lithological characteristics, the time intervals they represent or the } \\
\text { fossils they contain) or the boundaries between them. }\end{array}$ \\
\hline Major structural features & $\begin{array}{l}\text { Tectonic events and episodes associated with plate movements. Examples include } \\
\text { features associated with plate collisions resulting, for example, in formation of } \\
\text { mountain chains, accompanied by thrusting, folding and compression of strata. Other } \\
\text { examples associated with the convergence of plates include the formation of island } \\
\text { arcs, central volcanoes, and extensive lava flows. }\end{array}$ \\
\hline Formation of minerals & Rare and representative mineral deposits and locations of specific minerals. \\
\hline Evolution of life & $\begin{array}{l}\text { Fossils and fossil assemblages representing stages in the evolution of life and } \\
\text { gradations and interruptions in life sequences in the fossil record reflecting, } \\
\text { respectively, evolutionary trends and catastrophic events, such as meteorite strikes } \\
\text { and eruptions of supervolcanoes. }\end{array}$ \\
\hline Modern Earth processes & $\begin{array}{l}\text { Features representative of active processes particularly associated with tectonic } \\
\text { plates, such as different types of volcanoes and other eruptive forms, and those } \\
\text { associated with coastal, fluvial, arid, tropical, glacial and periglacial environments. }\end{array}$ \\
\hline $\begin{array}{l}\text { Representative surface and } \\
\text { sub-surface features }\end{array}$ & $\begin{array}{l}\text { Features representative of particular periods of Earth history, or particular rock } \\
\text { formations or Earth processes, or that are unusual or distinctive (e.g. cave systems, } \\
\text { earth pillars, domed and other upstanding rock formations). }\end{array}$ \\
\hline $\begin{array}{l}\text { Records of past } \\
\text { environments }\end{array}$ & $\begin{array}{l}\text { Rocks, fossils, landforms and sedimentary deposits indicative of past environments } \\
\text { and environmental changes from all periods of Earth history (e.g. the glacial and } \\
\text { interglacial phases of the Quaternary ice ages). }\end{array}$ \\
\hline
\end{tabular}

geoheritage aspects of existing protected areas that might require conservation and for places of importance for geoconservation that have not been formally identified and protected. In both cases, the first stage is to systematically identify the key components of geoheritage that should be protected. A simple schema is shown in Table 1 to aid this process.

The second stage is survey work to identify key aspects of value to geoheritage using the framework in Table 1 . This should result in the identification of target areas for protection. Depending on the purpose of the assessment, additional non-scientific criteria may be incorporated such as educational, cultural, aesthetic and ecological values (Reynard, 2009).

The third stage is to take a step-by-step approach to identify specific sites and areas for protection. A very useful practical tool to use at this stage is the Geoheritage Tool-kit (Brocx and Semeniuk, 2011) (Figure 2). An intrinsic part of this third stage is to review the need for site networks rather than just individual sites. These are important since it is often the case that multiple sites are necessary to represent the essential characteristics of a particular phenomenon or event in a country (e.g. the range of glacial landforms in Great Britain). In the case of major Earth features and processes, a purely national approach will not result in adequate representation. Take, for example, the opening of the North Atlantic Ocean arising from the separation of the Eurasian and North American tectonic plates, a major event in the Earth's history. Transnational collaboration is required to establish a network of protected sites fully representative of the key features and processes, incorporating key sites in each country around the Ocean and important sub-sea features in international waters.

The final stage is to use established national legal processes for formally protecting an area. Formal statutory protection is the preferred mechanism, but it is recognised that this cannot always be achieved for political or practical reasons. There are alternatives such as ownership by NGOs or communities; there are cases, for example in Britain, where this has occurred and the Joggins Fossil Cliffs case, highlighted above, is another. In addition, when communities and NGOs are developing new protected areas or reviewing the scope of existing ones, it is hoped that they will consider opportunities for protecting geoheritage. 


\begin{tabular}{|c|c|c|c|c|}
\hline \multirow[t]{2}{*}{$\begin{array}{l}\text { THE GEOHERITAGE TOOL-KIT } \\
\text { Step 1: determine/define the natural geological } \\
\text { region in which the area or site resides } \\
\text { (Western Australia, and the Kimberley } \\
\text { region used here as an example) } \\
\text { Step 2: from literature, interviews, fieldwork, identify/ } \\
\text { list the characteristic, peculiar, important or essential } \\
\text { geomorphic, stratigraphic, structural, mineralogic, } \\
\text { petrologic, hydrologic, diagenetic, pedologic, } \\
\text { palaeontologic, and other geologic features of the } \\
\text { area to develop an inventory of geoheritage features }\end{array}$} & \multicolumn{4}{|c|}{ 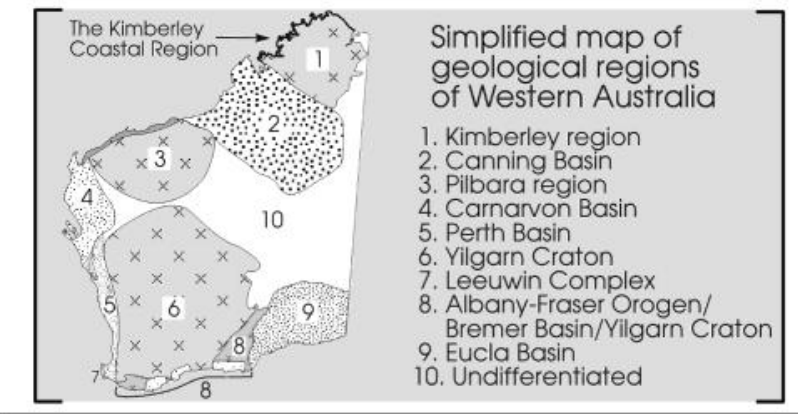 } \\
\hline & \multicolumn{4}{|c|}{ A CONCEPTUAL CATEGORIES OF SITES OF GEOHERIAGE SIGNIFICANCE } \\
\hline \multirow[b]{2}{*}{$\begin{array}{l}\text { Step 3: assign each of the features identified in Step } 2 \\
\text { to one of the categories of Geoheritage sites (Inset A) }\end{array}$} & & 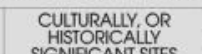 & $\begin{array}{l}\text { GEOHISTORICAL SIIES } \\
\text { (ANCIENT SEQUENCES) }\end{array}$ & $\begin{array}{l}\text { MODERN LANDSCAPES } \\
\text { AND SEIINGS }\end{array}$ \\
\hline & $\begin{array}{l}\text { ORLOCATION } \\
\text { GEOLOGICALEATURE } \\
\text { (A PRODUCT) }\end{array}$ & $\begin{array}{l}\text { SIGNIFACANT SIES } \\
\text { GEOLOGICAL FETURE } \\
\text { (A PRODUCA) }\end{array}$ & $\begin{array}{l}\text { SITES WHERE PROCESSES } \\
\text { CAN BEE NFERED } \\
\text { FROM PRODUCTS }\end{array}$ & \\
\hline & $\begin{array}{l}\text { Type stratigraphic } \\
\text { locations } \\
\text { Iype fossill locations } \\
\text { Iype sol locations } \\
\text { Iype geomorphic } \\
\text { locations }\end{array}$ & 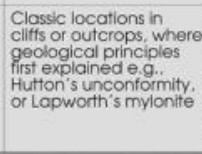 & 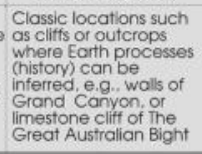 & 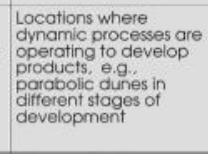 \\
\hline $\begin{array}{l}\text { Step 4: assign each of the features identified in Step } 2 \\
\text { to a scalar frame of reference (Inset B) }\end{array}$ & \multicolumn{4}{|c|}{ B SCALE OF GEOHERITAGE FEATURE (terrane, outcrop/bed, to crystal) } \\
\hline $\begin{array}{l}\text { Step 5: determine the level of significance } \\
\text { of each of the features (Inset C) }\end{array}$ & \multicolumn{4}{|c|}{ 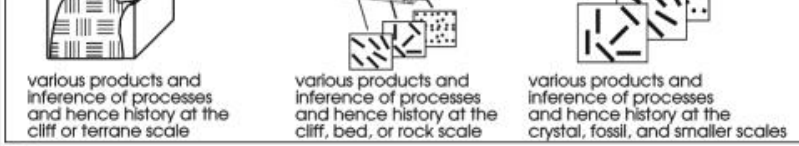 } \\
\hline \multirow{2}{*}{$\begin{array}{l}\text { Step 6: based on the range, category, inter-relations, } \\
\text { and level(s) of the significance of the geological } \\
\text { features, determine what type or what level of geo- } \\
\text { conservation the area requires according to prevailing } \\
\text { existing conservation categories }\end{array}$} & \multicolumn{4}{|c|}{\begin{tabular}{|l} 
C SIGNIFICANCE OF TERRANE, CLIFF, OUTCROP, BED, OR CRYSTAL FEATURE \\
Intemational $\longrightarrow$ National $\longrightarrow$ state/Regional $\longrightarrow$ local \\
\end{tabular}} \\
\hline & \multicolumn{4}{|c|}{$\begin{array}{l}\text { geological site, geosite, monument, geopark, } \\
\text { nature reserve, National Park, World Heritage site }\end{array}$} \\
\hline
\end{tabular}

Figure 2: Steps in the use of the Geoheritage Tool-kit to identify and assess sites of geoheritage significance.

Source: Brocx \& Semeniuk (2011), reproduced by permission of the authors and the Royal Society of Western Australia

The Geological Conservation Review in Great Britain is a good example of a systematic assessment of nationally important geosites (Ellis, 2011). The underlying rationale is that sites are selected for their scientific interest through a process of expert review, and must make a special contribution to the understanding and appreciation of Britain's geoheritage. Over 3,000 sites have been selected and most are designated as Sites of Special Scientific Interest (SSSIs) and have statutory protection.

\section{GUIDING PRINCIPLES FOR GEOCONSERVATION IN PROTECTED AREAS}

Identification and designation of protected areas is an essential first step in the conservation of features and processes of geoheritage significance. At least as important is the determination of the type of management required in the light of the reasons for protection and both the natural and human activities and events which might affect the integrity of the site or area (see Crofts \& Gordon, 2015). A number of guiding principles are provided below to aid this process.

1. Manage natural systems naturally: This guiding principle is based on the philosophy of working with nature rather than against it. As far as possible, natural systems and processes should be allowed to maintain natural rates and magnitudes of change and their capacity to evolve uninterrupted across most or all of their natural range of variability. If intervention is essential, mimicking nature and natural processes is more environmentally sustainable and effective than trying to impose engineered solutions that seek to control or halt natural processes. 'Soft' approaches to management should be adopted using natural materials that mimic nature as far as possible, rather than 'hard' engineering solutions that can wreck the features and processes of the protected area (e.g. Scottish Natural Heritage, 2000; River Restoration Centre, 2013). Good examples are along the coast where the emplacement of fixed structures to stem sediment loss might result in starving adjacent dynamic landforms and associated habitats; instead, alternative approaches including beach nourishment, managed realignment or use of 'green infrastructure' to enhance natural forms of defence such as sand dunes or salt marshes are recommended. For example, removal of mangroves, that serve as a natural form of protection of the coastal edge and are protected for their biological interest, and replacing them with solid structures such as concrete walls should be avoided. 
2. Natural systems and processes should be managed in a spatially integrated manner: Management of part of a natural system in isolation from other elements of the system should be avoided. For example along a coastline or in a mountain area or a river basin, management should seek to achieve complementary objectives, such as geodiversity, biodiversity and landscape diversity conservation, and recognise the effects of connectivity and dependencies between different parts of the system at the landscape scale (e.g. downstream habitat changes arising from changes in sediment transfer between hillslopes and river channels).

3. The inevitability of natural change should be recognised: No system or element of a natural system is static forever and change will occur. The traditional approach of maintaining or enhancing the current state to preserve features can remain valid where these are unlikely to be significantly affected by the natural changes, such as iconic mountains and robust rock features, or in the case of some small, high-value sites where protective measures can be effectively implemented. But, in many circumstances, where natural processes are a key element of maintaining or protecting the features of interest, it will have to be recognised that working with natural changes to allow geomorphological processes to adapt to the changed conditions may be the only effective strategy (Prosser et al., 2010; Sharples, 2011). This may mean the loss of some features, changes in their locations possibly outside the boundaries of the protected area, or their realignment. Where protection is deemed necessary, it may mean some form of 'soft' geoengineering, but this should only be undertaken provided that it is mimicking natural processes rather than seeking to modify them substantially or to destroy them (see above).

4. The effects of global climate change should be carefully considered: Climate change is an increasingly important issue and cannot be ignored just because there might remain some doubt about the relative contribution of natural and anthropogenic forcing. The resulting effects will inevitably challenge the management objectives of protected areas. Careful consideration will be needed where, for example, the features are lost and/or processes are lessened or intensified, and so change the basis for protection. It may mean that the protection status can no longer be justified at all or that features elsewhere have developed meriting protection where none previously existed. Site boundaries may also need to be altered to take account of coastal erosion or where dynamic features of interest shift location.
5. The sensitivity of natural systems should be recognised and they should be managed within the limits of their capacity to absorb change: It is rarely the case that abiotic systems are robust and can absorb any change imposed upon them. Some will be more able than others to absorb change and others will be very fragile with low thresholds for change. If limiting thresholds are crossed, the conservation effort will be negated as the original features and processes will have been irreversibly changed.

6. Conservation management of active systems should be based on a sound understanding of the underlying physical processes: This includes, for example, implementation of coastal cells work in preparation of shoreline management plans; integration of river, soil and slope processes in catchment management plans; and monitoring of active processes.

7. Make provision for managing visitors at sensitive sites: Some sites will be very sensitive. For example, sites with rare fossils and minerals need protection from the activities of commercial collectors and irresponsible fossil collecting which can damage the scientific interest and reduce the opportunities for more research. Other sites may be vulnerable to trampling which will damage and perhaps wreck fragile forms such as new lavas. Managing access through permit systems or through accompanied visits are obvious ways of dealing with sensitivity that protected area managers will be well familiar with. Where there is a cultural and/or spiritual interest in a site, consideration needs also to be given to the maintenance of traditional access.

8. Recognise the interaction and interdependency of geodiversity and biodiversity management: Many sites protected for biodiversity will have a high dependency on the geodiversity of the sites, and on other sites there will be a significant interrelationship between the biotic and abiotic elements (e.g. on sand dunes). Managers should take into account these interdependencies in managing sites. More details on these interactions are given below.

\section{INTERACTIONS BETWEEN GEODIVERSITY AND BIODIVERSITY CONSERVATION}

Interactions between geoheritage and biodiversity conservation can be both positive and negative. The negative elements need to be recognised and solutions found by protected area managers. The essence of the resolution should be recognition of the interconnections between the biotic and abiotic features and the processes that brought them into existence and those processes 


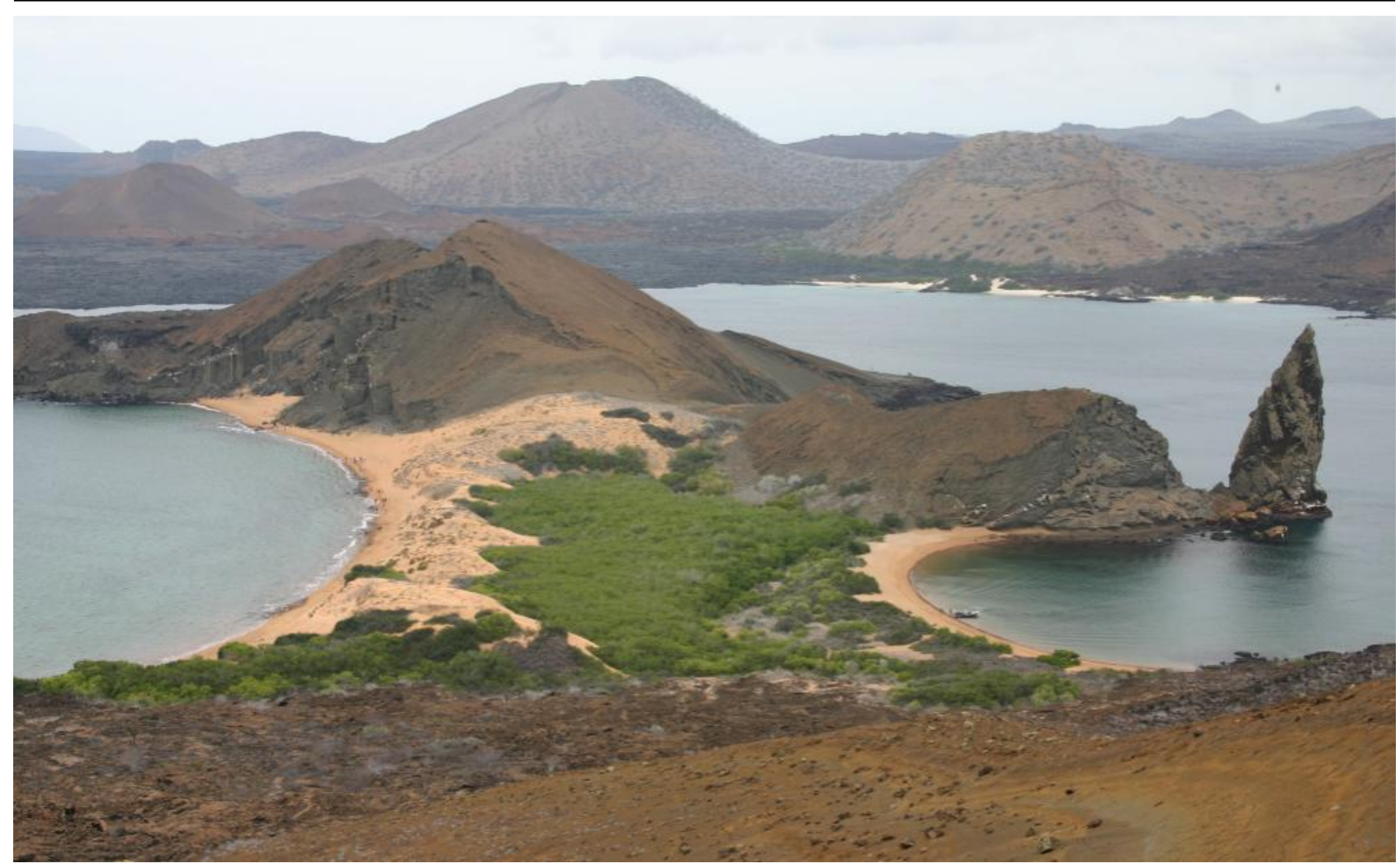

Galapágos Islands: volcanic activity and tectonic plate movement have created a succession of new islands, enhancing the geodiversity and providing the abiotic basis for the diversity of species within the archipelago @ Roger Crofts

which maintain them. Taking a one-dimensional approach, favouring either geoheritage or biodiversity conservation, is most unlikely to result in a resolution benefiting conservation as a whole. Issues which will need to be addressed include:

- What is the basis of the conflict between the biotic and abiotic interests in and around the protected area?

- Is the conflict capable of resolution without undermining both interests or is it more fundamental?

- If the latter, is one of the interests more important in the long term to national and international nature conservation than the other and needs to be safeguarded and the other sacrificed?

There will also be a series of practical issues to be addressed, such as:

- Is vegetation growth damaging or obscuring the geodiversity interest and would its removal or restraint damage the biodiversity interest? Alternatively, should the geodiversity interest be taken off-site or allowed to be obscured provided that it can be periodically re-exposed for re-examination in the light of new knowledge?

- Are current Earth processes, for example, glacier melt or river erosion, which are important for maintaining the geodiversity interest, having a damaging effect on the biodiversity interest? If so, can manipulation of the processes to have minimal effect on their natural pattern be undertaken to achieve biodiversity conservation benefits?

Sometimes, it will not be possible to achieve a solution at the protected area level, and the wider context of the habitat, ecosystem or biome will need to be considered in determining the relative merits of conserving one element in one place and the other in another place within the biogeographical unit.

Finally, it is important to discourage attempts to maximise habitat/species diversity by landscape modifications that result in the creation of incongruous landforms/landscapes (e.g. through raising the land surface by infill in areas of flat topography or creation of ponds with shapes that are atypical of local natural features) (Gray, 2013).

\section{GEOCONSERVATION AND THE IUCN MANAGEMENT CATEGORIES}

The IUCN Management Categories are equally relevant to abiotic sites as they are for biotic sites. But, there has been a working assumption that only Category III 'Natural Monument or Feature' is relevant to geoconservation. This is far from the case. Certainly, Category III is very important and many sites classified 
Table 2: Examples of geoconservation protected areas in the IUCN Management Categories

Sources: compiled from various sources and taken from Crofts \& Gordon (2015) with updates by the authors

\begin{tabular}{|c|c|c|}
\hline Category & National examples & World Heritage Site examples \\
\hline $\begin{array}{l}\text { la Strict nature } \\
\text { reserve }\end{array}$ & $\begin{array}{l}\text { Greenland Ice Cap, Greenland: ice cap } \\
\text { and nunataks; Geysir valley, Kronotsky } \\
\text { Zapovednik, Russia: volcanic features }\end{array}$ & $\begin{array}{l}\text { Macquarie Nature Reserve, Australia: Earth } \\
\text { mantle rocks; Surtsey, Iceland: biotic and } \\
\text { abiotic processes on new island formed } \\
1963-67\end{array}$ \\
\hline Ib Wilderness area & $\begin{array}{l}\text { Maspalomas Dunes Special Nature } \\
\text { Reserve, Spain: saltmarshes within } \\
\text { Pleistocene dunes; Noatak Wilderness, } \\
\text { Alaska, USA: river basin }\end{array}$ & $\begin{array}{l}\text { Putorana Plateau WHS, Russia: basalt } \\
\text { plateau }\end{array}$ \\
\hline II National park & $\begin{array}{l}\text { Giant Mountains, Czech Republic-Poland: } \\
\text { periglacial landforms and geodiversity- } \\
\text { biodiversity relationships }\end{array}$ & $\begin{array}{l}\text { Dolomit Bellunesi National Park, Italy: karst, } \\
\text { glaciokarst and reefs; Grand Canyon } \\
\text { National Park, USA: stratigraphic record and } \\
\text { arid land erosion; Yoho National Park, } \\
\text { Canada: Cambrian fossil beds (Burgess } \\
\text { Shale) in landscape protected area }\end{array}$ \\
\hline $\begin{array}{l}\text { III Natural } \\
\text { monument or } \\
\text { feature }\end{array}$ & $\begin{array}{l}\text { Jenolan Karst Conservation Reserve, } \\
\text { Australia: karst system; Bosques } \\
\text { Petrificados, Argentina: petrified forest }\end{array}$ & $\begin{array}{l}\text { Boodjamulla (Lawn Hill) National Park, } \\
\text { Australia: terrestrial vertebrate fossils; } \\
\text { Joggins Fossil Cliffs, Nova Scotia, Canada: } \\
\text { Carboniferous fossils }\end{array}$ \\
\hline $\begin{array}{l}\text { IV Habitat/species } \\
\text { management area }\end{array}$ & $\begin{array}{l}\text { Montserrat Mountain Partial Natural } \\
\text { Reserve, Spain: sedimentary rocks, caves } \\
\text { and mountain erosion forms; Lord Howe } \\
\text { Marine Park, Australia: volcanic seamount }\end{array}$ & $\begin{array}{l}\text { Galapágos National Park, Ecuador: modern } \\
\text { geological processes }\end{array}$ \\
\hline $\begin{array}{l}\text { V Protected } \\
\text { landscape/seascape }\end{array}$ & $\begin{array}{l}\text { Cairngorms National Park, UK: Earth } \\
\text { history and modern geomorphological } \\
\text { processes; Cabo be Gata-Níjar Natural } \\
\text { Park, Spain: volcanic and Quaternary } \\
\text { history; Lyngsalpan landscape protected } \\
\text { area, Norway: alpine mountains with } \\
\text { glaciers and associated landforms, } \\
\text { geodiversity protection; Vatnajökull } \\
\text { National Park, Iceland: subglacial } \\
\text { volcanoes and ice cap with associated } \\
\text { landforms }\end{array}$ & $\begin{array}{l}\text { Škocjan Caves Regional Reserve, Slovenia: } \\
\text { sink holes, caves and underground rivers }\end{array}$ \\
\hline $\begin{array}{l}\text { VI Protected area } \\
\text { with sustainable use } \\
\text { of natural resources }\end{array}$ & $\begin{array}{l}\text { Nublo Rural Park, Spain: volcanology, } \\
\text { geomorphology; Sečovlje Salina Nature } \\
\text { Park, Slovenia: salt extraction }\end{array}$ & $\begin{array}{l}\text { Great Barrier Reef National Park, Australia: } \\
\text { coral reef system evolution }\end{array}$ \\
\hline
\end{tabular}

around the world are testimony to this. In addition, however, geoconservation can be part of protected area rationales and management objectives for all of the other Categories. Table 2 provides examples for nationally protected areas and for World Heritage Sites to exemplify this point.

Although not a protected area category as such, Geoparks are areas with outstanding geoheritage established primarily to combine conservation of geoheritage with promotion of geotourism to support sustainable local economic and cultural development (McKeever et al., 2010). Geoparks may wholly, or in part, include protected areas and help to ensure their conservation. They may be set up through community-led initiatives or top-down designation. The Global Network of National Geoparks or Global Geoparks Network (GGN), assisted by UNESCO, provides an international framework of accreditation and standards for geoparks (UNESCO, 2010); currently the network comprises 100 national Geoparks worldwide (UNESCO 2014).

\section{THREATS TO GEOHERITAGE CONSERVATION}

There are many threats to the protection of geoheritage arising from human activities (Table 3). These need to be systematically considered in protected area management. 
Table 3: Principal human-induced threats to geoheritage in protected areas Source: adapted from Gordon \& Barron (2011), Brooks (2013) and Gray (2013)

\begin{tabular}{|c|c|}
\hline Threats and pressures & Examples of impacts on geoheritage in protected areas \\
\hline $\begin{array}{l}\text { Urbanisation, construction (including } \\
\text { commercial and industrial developments } \\
\text { inland and on the coast), infrastructure, } \\
\text { renewable energy installations }\end{array}$ & $\begin{array}{l}\text { - destruction of landforms and exposures of sediments and rocks } \\
\text { - } \\
\text { - } \text { disrugmentation of site integrity and loss of relationships between features } \\
\text { - } \text { destruction of soils and soil structure } \\
\text { - changes to soil and water regimes }\end{array}$ \\
\hline $\begin{array}{l}\text { Mining and mineral extraction (including } \\
\text { extraction from opencast mines, pits, } \\
\text { quarries, dunes \& beaches, river beds, } \\
\text { marine aggregate extraction and deep-sea } \\
\text { mining) }\end{array}$ & $\begin{array}{l}\text { - destruction of landforms and exposures of sediments and rocks } \\
\text { - } \\
\text { - } \text { dragmentation of site integrity and loss of relationships between features } \\
\text { - } \\
\text { - } \\
\text { destruction of soils and soil structure } \\
\text { changes to soil and water regimes }\end{array}$ \\
\hline $\begin{array}{l}\text { Changes in land use and management } \\
\text { (including agriculture, forestry) }\end{array}$ & $\begin{array}{l}\text { - landform damage through ploughing, ground levelling and drainage } \\
\text { - } \quad \text { loss of landform and outcrop visibility and access to exposures } \\
\text { - } \quad \text { soil erosion } \\
\text { - changes to soil chemistry and soil water regimes } \\
\text { - } \quad \text { soil compaction and loss of organic matter }\end{array}$ \\
\hline $\begin{array}{l}\text { Coastal protection and river management } \\
\text { and engineering (including dams and } \\
\text { water abstraction) }\end{array}$ & $\begin{array}{l}\text { - damage to landforms and exposures of sediments and rocks } \\
\text { - loss of access to exposures } \\
\text { - disruption of geomorphological processes } \\
\text { - inhibition of erosion allows exposures to become degraded }\end{array}$ \\
\hline $\begin{array}{l}\text { Offshore activities (including dredging, } \\
\text { trawling, renewable energy } \\
\text { developments, hydrocarbon exploitation } \\
\text { and waste disposal) }\end{array}$ & $\begin{array}{l}\text { - } \quad \text { physical damage to landforms and sediments } \\
\text { - } \text { disruption of geomorphological processes } \\
\text { - } \quad \text { seabed and sub-seabed surface scour/penetration }\end{array}$ \\
\hline Recreation and geotourism & $\begin{array}{l}\text { - physical damage to landforms, rock outcrops, processes and soils (compaction) } \\
\text { through visitor pressure } \\
\text { - fragmentation of site integrity } \\
\text { - footpath erosion and other localised soil erosion and loss of soil organic matter }\end{array}$ \\
\hline Climate change & $\begin{array}{l}\text { - } \quad \text { changes in active system processes } \\
\text { - } \quad \text { changes in system state (reactivation or stabilisation) } \\
\text { - loss of key features, such as ice caps and glaciers, glacial lakes and outflows }\end{array}$ \\
\hline Sea-level rise (anthropogenic causes) & $\begin{array}{l}\text { - loss of visibility and access to coastal exposures and outcrops through } \\
\text { submergence } \\
\text { - } \quad \text { loss of exposures through enhanced erosion } \\
\text { - } \quad \text { loss of all or substantial parts of protected areas } \\
\text { - } \quad \text { new features developed (e.g. from storm surges) }\end{array}$ \\
\hline $\begin{array}{l}\text { Restoration of pits and quarries (including } \\
\text { landfill) }\end{array}$ & - loss of exposures and natural landforms \\
\hline $\begin{array}{l}\text { Stabilisation of rock faces (e.g. road } \\
\text { cuttings) with netting and concrete }\end{array}$ & - loss of exposures \\
\hline $\begin{array}{l}\text { Irresponsible fossil and mineral collecting } \\
\text { and rock coring }\end{array}$ & - $\quad$ physical damage to rock exposures and loss of fossil record \\
\hline
\end{tabular}

\section{ESTABLISHING MONITORING AND EVALUATION SYSTEMS}

Finally, as with any protected areas, systems for monitoring and evaluating the state of protection are necessary and in particular to determine whether the geoheritage features and forms, and the natural processes operating to ensure retention of the interests, are being protected. In addition to the standard Management Effectiveness Evaluation systems recommended by IUCN WCPA (Hockings et al., 2006), some additional measures relating to site and process integrity are required specifically for geoheritage sites (Table 4, overleaf). 
Table 4: Protected area geoheritage attributes to be monitored. Source: adapted from Ellis (2004)

Visibility of features: the degree of concealment from the build-up of vegetation, soil or talus, or from constructions
and other human activities
Site integrity: the degree of fragmentation, degradation or physical damage affecting the features of interest
Extent of features: the area of rock face, sediment section or landforms available for study or interpretation, or the
quantity of important geological material such as the volume of spoil material in a mine dump
Integrity of dynamic processes: the freedom of geomorphological processes to evolve naturally and unimpeded

\section{ENDNOTES}

${ }^{1}$ To apply for individual membership of the WCPA Geoheritage Specialist Group contact the Secretary General, Wesley Hill,whill@geosociety.org

${ }^{2}$ See: www.iucn.org/about/work/programmes/gpap_home/ gpap_biodiversity/gpap_wcpabiodiv/gpap_geoheritage/

${ }^{3}$ See: www.pc.gc.ca/eng/pn-np/bc/yoho/natcul/burgess.aspx

${ }^{4}$ See: www.nature-shetland.co.uk/snh/hamar.htm

${ }^{5}$ www.waimangu.co.nz/

${ }^{6}$ See: www.jogginsfossilcliffs.net

${ }^{7}$ See: www.vatnajokulsthjodgardur.is/english

${ }^{8}$ See: www.krnap.cz/en/

\section{ACKNOWLEDGEMENTS}

We are grateful to colleagues in the IUCN WCPA Geoheritage Specialist Group and ProGEO who commented on the extended statement to be published in the WCPA Protected Area Governance and Management book, on which some of the material in this article is based. Thanks to Nigel Dudley for comments and encouragement.

\section{ABOUT THE AUTHORS}

Roger Crofts trained as a geographer and carried out geomorphological research in mid and high latitudes. Following work in the Scottish Government, he was the founder Chief Executive of Scottish Natural Heritage 1992-2002, including managing and advising on management of protected areas and the implementation of Natura 2000. He was WCPA Regional Vice-Chair Europe 2000-2008, chair of the IUCN UK Committee 1999-2002, chaired the Durban Working Party for the Vth World Parks Congress and is now a WCPA Emeritus. He has written and lectured on Earth heritage and environmental management, particularly in Scotland, Iceland and other parts of Europe. www.rogercrofts.net

John E Gordon is a geomorphologist who has worked on geoconservation in the UK with the Nature Conservancy Council, Scottish Natural Heritage and currently as an adviser and consultant. He is an honorary professor in the School of Geography and Geosciences at the University of St Andrews and is a deputy chair of the IUCN/WCPA Geoheritage Working Group and a member of the European Federation of Geologists' Panel of Experts on Geoheritage. He has published many articles and books on geoheritage and geoconservation and on his other research interests in mountain geomorphology, glaciers and glaciation.

\section{REFERENCES}

Alexandrowicz, Z. and Margielewski, W. (2010). Impact of mass movements on geo- and biodiversity in the Polish Outer (Flysch) Carpathians. Geomorphology, 123, pp.290304. DOI: 10.1016/j.geomorph.2010.07.020

Anderson, M. G. and Ferree, C. E. (2010). Conserving the stage: climate change and the geophysical underpinnings of species diversity. PLOS ONE 5(7): e11554.DOI:10.1371/ journal.pone.0011554.

Barthlott, W., Mutke, J., Rafiqpoor, M. D., Kier, G. and Kreft, H. (2005). Global centres of vascular plant diversity. Nova Acta Leopoldina, 92, pp.61-83.

Brocx, M. and Semeniuk, V. (2011). The global geoheritage significance of the Kimberley Coast, Western Australia. Journal of the Royal Society of Western Australia, 94, pp.57-88.

Brooks, A. J. (2013). Assessing the sensitivity of geodiversity features in Scotland's seas to pressures associated with human activities. Scottish Natural Heritage Commissioned Report No. 590. <http://www.snh.gov.uk/publicationsdata-and-research/publications/search-the-catalogue/ publication-detail/?id=2036>

Convention on Biological Diversity (1992). Convention on Biological Diversity. Montreal, Canada: UNEP-CBD.

Coratza, P. and Panizza, M. (eds) (2009). Geomorphology and cultural heritage. Memorie Descrittive della Carta Geologica d'Italia, 87, 192pp.

Crofts, R. (2014). Promoting geodiversity: learning lessons from biodiversity. Proceedings of the Geologists' Association, 125, pp.263-266. DOI: 10.1016/ j.pgeola.2014.03.002

Crofts, R. and Gordon, J. E. (2015). Geoconservation in protected areas. In: G. L. Worboys, M. Lockwood, A. Kothari, S. Feary and I. Pulsford (eds) Protected Area Governance and Management. Canberra: ANU Press.

Crofts, R., Harmon, D. and Figgis, P. (2008). For Life's Sake: How Protected Areas Enrich our Lives and Secure the Web of Life. Gland, Switzerland: IUCN World Commission on Protected Areas.

Davey, A. G. (1998). National Systems Planning for Protected Areas. IUCN World Commission on Protected Areas Best Practice Guideline Series no. 1. Gland, Switzerland and Cambridge, UK: IUCN.

Díaz-Martínez, E. (2011). Typology of heritage: Where does geoheritage fit in? Forum GeoReg, Villeneuve d'Ascq, France, 23-27 October 2011, -Résumés/Abstracts, p.102. <http://www.igme.es/internet/patrimonio/publicaciones/ congresos/D\%C3\%ADaz-Mart\%C3\%ADnez\%202011\%20-\% 
20Typology\%20of\%20geoheritage\%20-\%20GeoReg\% 20\&\%20SW-ProGEO\%20Meeting.pdf >

Dowling, R. K. and Newsome, D. (2010). Global Geotourism Perspectives. Oxford, England: Goodfellow Publishers.

Dudley, N. (ed) (2008). Guidelines for Applying Protected Area Management Categories. Gland, Switzerland: IUCN.

Dudley, N. and Stolton, S. (eds) (2008). Defining Protected Areas: an International Conference in Almeria, Spain. Gland, Switzerland: IUCN.

Ellis, N. (2004). Common Standards Monitoring Guidance for Earth Science Sites. Peterborough, England: Joint Nature Conservation Committee. <jncc.defra.gov.uk/pdf/ CSM_earth_science.pdf>

Ellis, N. (2011). The Geological Conservation Review (GCR) in Great Britain - rationale and methods, Proceedings of the Geologists' Association, 122, pp.353-362. DOI: 10.1016/ j.pgeola.2011.03.008

Geological Society of America (2012). GSA Position Statement: Geoheritage.<http://www.geosociety.org/positions/ pos20_Geoheritage.pdf>

Gordon, J. E. and Barron, H. F. (2011). Scotland's geodiversity: development of the basis for a national framework. Scottish Natural Heritage Commissioned Report, No. 417. <http://www.snh.org.uk/pdfs/publications/ commissioned_reports/417.pdf>

Gray, M. (2013). Geodiversity: Valuing and Conserving Abiotic Nature. $2^{\text {nd }}$ edition. Chichester, England: Wiley-Blackwell.

Gray, M., Gordon, J. E. and Brown, E. J. (2013). Geodiversity and the ecosystem approach: the contribution of geoscience in delivering integrated environmental management. Proceedings of the Geologists' Association, 124, pp.659-673. DOI: 10.1016/j.pgeola.2013.01.003

Guttormsson, H. (2011). Vatnajökull National Park - a Guidebook. Reykjavík, Iceland: Friends of Vatnajökull Vinir Vatnajökuls.

Hockings, M., Stolton, S., Leveringham, F. and Dudley, N. (2006). Evaluating Effectiveness: a Framework for Assessing the Management of Protected Areas. Gland, Switzerland and Cambridge, UK: IUCN.

Hutton, J. (1788). Theory of the Earth; or an investigation of the laws observable in the composition, dissolution, and restoration of land upon the globe. Transactions of the Royal Society of Edinburgh, 1, pp.209-304.

IUCN (1994). Guidelines for Protected Area Management Categories. Gland, Switzerland: IUCN.

IUCN (2008). Resolutions and Recommendations, World Conservation Congress, Barcelona, 5-14 October 2008, WCC-2008-Res-040: Conservation of geodiversity and geological heritage. Gland, Switzerland: IUCN. <https:// portals.iucn.org/library/node/44190>

IUCN (2012). Resolutions and Recommendations, World Conservation Congress, Jeju, Republic of Korea, 6-15 September 2012, WCC-2012-Res-048: Valuing and conserving geoheritage within the IUCN Programme 20132016. Gland, Switzerland: IUCN. <https://portals.iucn.org/ library/node/44015>

Jeník, J. (1997). Anemo-orographic systems in the Hercynian Mts and their effects on biodiversity. Acta Universitatis Wratislaviensis, No. 1950. Prace Instytutu Geograficznego, Seria C. Meteorologia i Klimatologia, 4, pp.9-21.

Langhammer, P. F., Bakarr, M. I., Bennun, L. A., Brooks, T. M., Clay, R. P., Darwall, W., De Silva, N., Edgar, G. J., Eken, G., Fishpool, L. D. C., da Fonseca, G. A. B., Foster, M. N., Knox, D. H., Matiku, P., Radford, E. A., Rodrigues, A. S. L., Salaman, P., Sechrest, W. and Tordoff, A. W. (2007).
Identification and Gap Analysis of Key Biodiversity Areas: Targets for Comprehensive Protected Area Systems. Gland, Switzerland: IUCN.

le Roux, P. C. and Luoto, M. (2014). Earth surface processes drive the richness, composition and occurrence of plant species in an arctic-alpine environment. Journal of Vegetation Science, 25, pp.45-54. DOI: 10.1111/jvs.12059

McKeever, P. J., Zouros, N. and Patzak, M. (2010). The UNESCO Global Geoparks Network. European Geoparks Magazine, 7, pp.10-13.

ProGEO (2011). Conserving our shared geoheritage - a protocol on geoconservation principles, sustainable site use, management, fieldwork, fossil and mineral collecting. $<$ http://www.progeo.se/progeo-protocol-definitions20110915.pdf>

Prosser, C. D. (2013). Our rich and varied geoconservation portfolio: the foundation for the future. Proceedings of the Geologists' Association, 124, pp.568-580. DOI: 10.1016/j.pgeola.2012.06.001

Prosser, C. D., Burek, C. V., Evans, D. H., Gordon, J. E., Kirkbride, V. B., Rennie, A. F. and Walmsley, C. A. (2010). Conserving geodiversity sites in a changing climate: management challenges and responses. Geoheritage, 2, pp.123-136. DOI: 10.1007/s12371-010-0016-7

Reynard, E. (2009). Geomorphosites: definitions and characteristics. In: E. Reynard, P. Coratza and G. RegoliniBissig (eds) Geomorphosites, pp.9-20. Munich: Verlag Dr. Friedrich Pfeil.

River Restoration Centre (2013). Manual of River Restoration Techniques. Cranfield, UK: The River Restoration Centre. $<w w w$. therrc.co.uk/rrc_manual.php>

Scottish Natural Heritage (2000). A Guide to Managing Coastal Erosion in Beach/Dune Systems. Battleby, Scotland: Scottish Natural Heritage. <www.snh.gov.uk/ publications-data-and-research/publications/search-thecatalogue/publication-detail/?id=112>

Sharples, C. (2002). Concepts and Principles of Geoconservation. Tasmanian Parks \& Wildlife Service, Hobart. <http://www.dpiw.tas.gov.au/inter.nsf/ Attachments/SJON-57W3YM/\$FILE/geoconservation.pdf>

Sharples, C. (2011). Potential climate change impacts on geodiversity in the Tasmanian Wilderness World Heritage area: a management response position paper. Nature Conservation Report Series 11/04, Resource Management and Conservation Division, Department of Primary Industries, Parks, Water and Environment, Hobart. <http://www.dpiw.tas.gov.au/inter,nsf/Attachments/ LEM-8P983Y?open>

Soukupová, L., Kociánová, M., Jeník, J. and Sekyra, J. (1995). Arctic-alpine tundra in the Krkonoše, the Sudetes. Opera Corcontica, 32, pp.5-88.

Štursa, J. (1998). Research and management of the Giant Mountains' arctic-alpine tundra (Czech Republic). Ambio, 27, pp.358-360.

Štursa, J. (2013). The development of opinions on the geobiodiversity of the Giant Mountains' arctic-alpine tundra and its conservation. Opera Corcontica, 50/S, pp.55-74.

Tansley, A. G. (1935). The use and abuse of vegetational c o $\mathrm{n} \mathrm{c} \mathrm{e} \mathrm{p} \mathrm{t} \mathrm{s} \mathrm{a} \mathrm{nd} \quad \mathrm{t}$ e $\mathrm{r}$ m s. Ecology, 16, pp.284-307.

Thorp, J. H., Flotemersch, J. E., Delong, M. D., Casper, A. F., Thoms, M. C., Ballantyne, F., Williams, B. S., O'Neill, B. J. and Haase, C. S. (2010). Linking ecosystem services, 
rehabilitation, and river hydrogeomorphology. BioScience, 60, pp.67-74. DOI: 10.1525/bio.2010.60.1.11

United Nations Educational, Scientific and Cultural Organisation (UNESCO) (2010). Guidelines and Criteria for National Geoparks Seeking UNESCO's Assistance to Join the Global Geoparks Network (GGN). Paris: UNESCO.
<http://www.globalgeopark.org/UploadFiles/2012_9_6/ GGN2010.pdf>

United Nations Educational, Scientific and Cultural Organisation (UNESCO) (2014). Earth Sciences for Society. Paris: UNESCO. <http://www.unesco.org/new/en/naturalsciences/environment/earth-sciences/globalgeoparks/>

\section{RESUMEN}

El reconocimiento formal del componente de geodiversidad de las áreas protegidas se dio en 2008 en las Directrices revisadas de la UICN para la aplicación de las categorías de manejo de las áreas protegidas. Este artículo defiende la importancia de esta adición y demuestra la necesidad de la conservación del patrimonio geológico en las áreas protegidas, tanto por derecho propio como por su valor más amplio en el apoyo a la biodiversidad y los servicios de los ecosistemas. El artículo resume algunas de las cuestiones claves que los administradores de áreas protegidas habrán de abordar para garantizar que la geoconservación se refleje adecuadamente en el desarrollo y la gestión de áreas protegidas. Se ofrece orientación preliminar sobre el desarrollo de la geoconservación en las áreas protegidas y la pertinencia de las seis categorías de manejo.

\section{RESUME}

En 2008 l'UICN a formellement reconnu l'importance de la composante de géo-diversité dans les aires protégées à travers la révision des Lignes directrices pour l'Application des Catégories de Gestion des Aires protégées. Cet article souligne l'importance de cette révision et présente les arguments en faveur de la conservation du géo-patrimoine dans les aires protégées, à la fois pour sa valeur intrinsèque et pour son importance plus vaste dans la préservation de la biodiversité et des services éco-systémiques. L'article résume certaines questions clés que les gestionnaires des aires protégées devront affronter pour s'assurer que la géo-conservation est bien prise en compte dans le développement et la gestion des aires protégées. Il fournit également une orientation préliminaire sur le développement de la géo-conservation dans les aires protégées et l'importance des six catégories de gestion. 